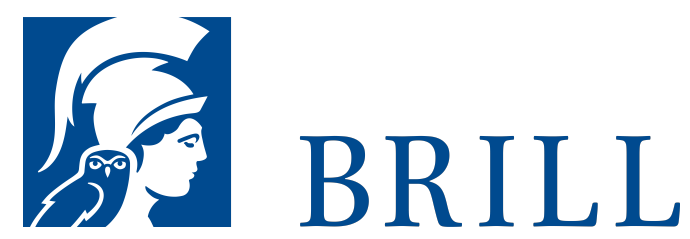

\title{
On Coerced Labor
}

Work and Compulsion after Chattel Slavery

Volume Editors: Marcel M. van der Linden and

Magaly Rodríguez García

On Coerced Labor focuses on those forms of labor relations that have been overshadowed by the "extreme" categories (wage labor and chattel slavery) in the historiography. It covers types of work lying between what the law defines as "free labor" and "slavery." The frame of reference is the observation that although chattel slavery has largely been abolished in the course of the past two centuries, other forms of coerced labor have persisted in most parts of the world. While most nations have increasingly condemned the continued existence of slavery and the slave trade, they have tolerated labor relationships that involve violent control, economic exploitation through the appropriation of labor power, restriction of workers' freedom of movement, and fraudulent debt obligations.

Contributors are: Lisa Carstensen, Christian G. De Vito, Justin F. Jackson, Christine Molfenter, David Palmer, Nicola Pizzolato, Luis F.B. Plascencia, Magaly Rodríguez García, Kelvin SantiagoValles, Nicole J. Siller, Marcel van der Linden, Sven Van Melkebeke.

\section{Readership}

MA students, and junior and senior researchers interested in the history of work, as well as anyone concerned with contemporary debates on human trafficking and so-called "modern slavery".

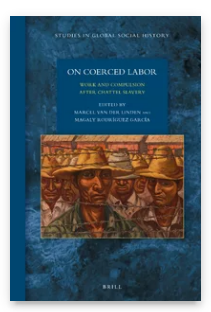

Pages: xiv, 373 pp.; incl. 4 maps, 8 tables and 4 figures Language:

English

Subjects: Social History, History, Global History,

History,

Humanitarian

Law, Human

Rights and

Humanitarian

Law, Global

Studies, Social

Sciences,

International

Organizations,

International

Law

Publisher: Brill

Series:

Studies in Global Social History,

Volume: 25

E-Book (PDF)

Released online: 10 Jun 2016

ISBN: 978-90о4-31638-6

List price

USD \$201.00 
Hardback

Publication date:

16 Jun 2016

Marcel van der Linden is Senior Fellow at the International Institute of Social History, Professor of Social Movement History at the University of Amsterdam, and President of the International Social History Association.

Magaly Rodríguez García is Assistant Professor at the University of Leuven, Belgium. She has published on human trafficking and child labor, the history and definitions of prostitution, including "Defining Commercial Sexualities, Past and Present" (Ashgate, 2016).

For more information see brill.com

ISBN: $978-90-$

O4-31637-9

List price

USD \$2O1.00

Paperback

Publication date:

16 Jun 2016

ISBN: 978-90-

O4-32643-9

List price

USD $\$ 72.00$

Order information: Order online at brill.com

+44330 3330049 | customerservices@brill.com

Submission information: brill.com/authors

Titles published by Brill | Fink, Brill | mentis or Brill | Schöningh: +49(o)71 5413279216 | brill@brocom.de 